\title{
A transdisciplinary exploration: Reading peace education and teaching English to speakers of other languages through multiple literacies theory
}

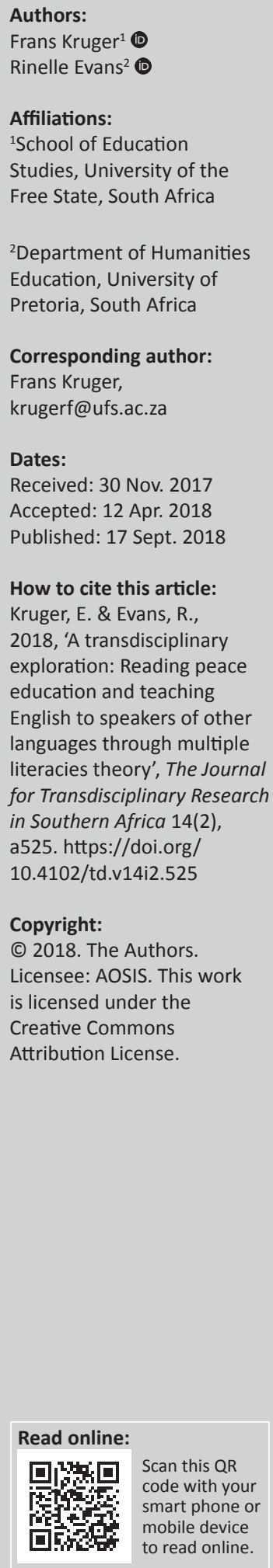

Since the early 1990s peace education has increasingly informed the field of teaching English to speakers of other languages (TESOL). More recently, this transdisciplinary dialogue has found expression in approaches such as peace linguistics, peace sociolinguistics and contentbased language instruction that incorporate peace-related content into language learning curricula. In this conceptual article, we aim to contribute towards the transdisciplinary possibilities generated between peace education and TESOL by reading these possibilities through the lens of the multiple literacies theory (MLT). We set out to argue that MLT offer a means to explore the connections between peace education and literacies as entangled with affective, material and discursive practices.

\section{Introduction}

In this article, we consider the potential of transdisciplinarity as it finds expression in the fields of peace education and teaching English to speakers of other languages (TESOL). Transdisciplinarity starts from a position that recognises 'the inherent complexity of reality' (Bernstein 2015:para. 30) and sets out to explore the often overlooked connections between different fields of study. To explore what we believe to be instances of such overlooked connections between the fields of peace education and TESOL, we draw on the multiple literacies theory (MLT) (Masny 2010; Masny \& Cole 2009; Masny \& Waterhouse 2011; Waterhouse 2011).

Before setting out our argument, it is important to highlight two points. The first is to recognise that TESOL is a relatively small field within the South African education landscape. Although small, the field can be subdivided into three areas. Firstly, TESOL finds expression in non-degree short courses offered by universities (e.g. University of South Africa, University of the Witwatersrand Language School, University of Cape Town English Language Centre and Nelson Mandela University's Unit for Continuing Education), as well as private institutions. Upon successful completion, one is (usually) qualified to teach English as a second (ESL) or foreign language (EFL) either within South Africa, or as more often the case, internationally. To a lesser extent, TESOL is also offered as a postgraduate qualification at a few South African universities (e.g. Stellenbosch University and University of South Africa).

The second area associated with TESOL involves English for academic purposes (EAP) programmes offered at both privately owned language institutions and language centres associated with specific universities (e.g. University of the Witwatersrand and University of KwaZulu-Natal) (Jordaan 2011). These programmes are most often attended by international adult language learners who wish to obtain the prerequiste academic English language proficiency (Cummins 2008) to enroll for study at a South African university. The third area associated with TESOL in South Africa involves short courses (e.g. English for Specific Purposes, English for Academic Purposes and English as a second or foreign language), ranging from two weeks to one year, offered mostly by private language institutions to international adult learners.

Secondly, we acknowledge that the field of TESOL is not unproblematic and that it is criticised for contributing to the spread of a globalised hegemony closely associated with neo-liberal capitalism (see, e.g. Masny \& Waterhouse 2016). We also work from the premise that English language teaching and learning are not neutral or value-free practices (Pennycook 2006; Phillipson 2009). It is precisely these problematic aspects of TESOL from which our research emerges and from where we set out to explore the transdisciplinary connections between peace education and TESOL. 
In what follows, we introduce MLT in order to consider how this theoretical orientation allows us to interrogate the complexity of the connections between peace education and TESOL. In doing this, we specifically consider the critiques offered by scholars such as Bajaj (2008), Gur-Ze'ev (2001, 2010, 2011) and Zembylas and Bekerman (2013) on how peace education is conventionally framed in order to explore the different connections made evident between peace education and TESOL through employing MLT.

\section{Multiple literacies theory}

Multiple literacies theory was developed by Dianne Masny; it seeks to make evident that literacies do not only involve learning the correct language codes but they are also about 'desire, about transformation, becoming Other than through continuous investments in reading, reading the world, and reading the self as text' (Masny 2009:15). Within MLT, literacies are conceptualised as a social construct expressed 'through words, gestures, attitudes, ways of speaking, writing, [and] valuing' (Masny 2009:13; 2010) that take on multiple meanings. Literacies are constituted through multimodal texts that become fused with 'religion, gender, race, culture, and power' (Masny 2009:13).

Cole (2013a:39) argues that from an MLT perspective, literacy does not only reflect 'being able to speak and listen, read and write, but is any form of communication in life'. Furthermore, within this theoretical position, a person is conceptualised as 'a text in continuous becoming' (Masny 2009:15). For researchers that draw on MLT, this conceptualisation enables one to foreground the flows of life experiences and events through which individuals become literate. Within this context, and although constituted along the same continuum, the difference between becoming literate and becomingliterate is of significance. To become literate refers to achieving predetermined outcomes that indicate whether one has obtained the desired proficiency, ability and skills in a particular target language. In contrast to this, Cole (2012a:33) argues that becoming-literate comprises a 'multi-directional and dimensional notion' of literacy that involves 'convergence [of] assemblage[s] ... that often chaotically collide in language learning spaces'. Becoming-literate thus takes cognisance of the myriad factors that impact on learning a language by attending to more than the transition 'from being illiterate to literate' (Cole 2012a:33). This in turn enables one to focus on the connections forged between various elements and allows for transformations to occur through investment in literacies.

It is through positing literacies 'as ongoing processes whose directions, multiplicities of possible lines of flight, are not predictable a priori' (Masny 2009:14) that allows for this concept to be understood as involving 'creative and productive processes' (Masny \& Waterhouse 2011:290). These processes, argue Masny and Waterhouse, are ongoing and emerge from events that stem from life experiences as one reads the self and the world as texts. Masny and Waterhouse's use of event in this instance draws on an understanding thereof as an occurrence that unfolds based on the dynamic interaction of various affective forces. Within MLT, events are understood as the 'moments that create ruptures and difference that allow for creativity to take off along various planes, similar to a rhizome ${ }^{1 \prime}$ (Masny 2010:340). It is the creation of these ruptures and differences that create the conditions for transformation to occur. Yet, in stark contrast to conventional approaches in applied linguistics that foreground linear transformation or developing proficiency in a language in terms of a programmatic logic (illiterate to literate), from an MLT perspective, although it is recognised that transformation will inevitably form part of the learning process, towards what end, however, cannot be foreseen. Learning is not a linear process but responses to an unfolding of life experiences and events. As such, the transformations produced through learning (a new language such as English) have 'neither beginnings nor endpoints, only entry and exit points that allow for more connections to be continuously created' (Masny 2010:341). Thus, MLT emerges from the random collision of affects present in the teaching and learning context as it 'examines the processes and manners in which these literate behaviours come together through becoming with the world' (Masny \& Cole 2009:6).

This understanding of MLT is based on the idea that reading is both an intensive (or disruptive) and an immanent activity (Masny \& Waterhouse 2011) that involves 'constant movement - from a territory (of bounded stability) through a deterritorialisation (a disruption) to a reterritorialisation (on a different territory, a different mapping) - in the process of becoming other' (Masny 2010:339). Deleuze's (1995) assertion that reading concerns not so much exploring what a text means but rather what connections and functions it produces forms the basis of this understanding of reading. For Deleuze (1995):

There are, you see, two ways of reading a book; you either see it as a box with something inside and start looking for what it signifies, and then if you're even more perverse or depraved you set off after signifiers. And you treat the next book like a box contained in the first or containing it. And you annotate and interpret and question, and write a book about the book, and so on and on. Or there's the other way: you see the book as a little non-signifying machine, and the only question is 'Does it work, and how does it work?' How does it work for you? If it doesn't work, if nothing comes through, you try another book. (pp. 7-8)

Thus, reading does not only involve the encoding and decoding of texts in order to determine what it signifies but is also about what connections it makes possible and the possible transformations that such connections may produce. It is this second aspect of reading as described by Deleuze that informs MLT and through which it is posited as an intensive and immanent activity. Masny and Waterhouse (2011) explain this understanding of reading as follows:

Take this example: you are at work; you are walking down the hallway. You smell coffee and look at the clock to see that it is four o'clock. The coming together of the walk down the hallway,

1.Deleuze and Guattari (1987) employ the figuration of the rhizome to map "a process of networked, relational and transversal thought' and to '... conceive how everything of networked, relational and transversal thought' and to '... conceive how everything
and everybody ... can be seen as multiple in their interrelational movements with other things and bodies' (Colman 2010:232-233): 
the smell of coffee, and seeing the time disrupts (reading intensively) and brings on the thought of vacation, the thought of it's time to go home, the thought of ... (reading immanently). (p. 292)

In positioning reading as an intensive and immanent activity allows for the creative and productive aspects thereof to be foregrounded and to posit it as the emergence of sense. Deleuze argues that sense is an event because it does not express 'what something is but its power to become' (Colebrook 2002:60). It is this conceptualisation of reading within MLT that allows for it to explore how 'words, notes and icons are actualised in situ and in interested ways' (Masny 2010:340) and how in reading the self and the world as texts enables one to explore 'ways of becoming with the world' (Masny 2010:338).

Having considered some of the main aspects of MLT, we turn our attention to the emergent understandings of peace and how these understandings are also reflected in approaches to a peace education proposed by Bajaj (2008), Gur-Ze'ev (2001, 2010, 2011) and Zembylas and Bekerman (2013). After having considered these selected approaches, we read them through the lens of MLT to explore the transdisciplinary possibilities this makes possible between the fields of peace education and TESOL.

\section{Emerging conceptualisations of peace and approaches to peace education}

The manner in which peace education and peace theory inform TESOL (see, e.g. Kruger 2012; Waterhouse 2011) relies to a large extent on a normative and universalised understanding of what constitutes peace and violence (see, e.g. Danesh 2005). This is not in itself problematic but arguably allows for only some of the connections between peace education and TESOL to be explored within our research and teaching endeavours and how these find expression in our practice. Normative and universalised understandings of peace and violence have been problematised in both peace theory and how these find expression within peace education. In providing only the position of a few scholars, we do not claim that their views are either representative or exhaustive. Rather, we choose to consider their work because we believe it complements important aspects of MLT.

Within peace studies, Webel (2007:7) argues that peace is dialectically determined and should be conceptualised as 'an ideal without an essence, an "ideal type"'. As a concept whose meaning remains both a historical ideal and one in constant flux, peace revolves around personal and collective ethical transformation through goals and means that are continual. As such, peace becomes an intrapersonal and intersubjective praxis immanent to a particular event. In a similar vein, Cubitt (2002) troubles the received understanding of peace and violence by questioning the binary opposition that governs this position. Such an understanding, he argues, does not offer any grounds for progress towards the ideal of peace. Accordingly, peace should be approached as being post-rational. Central to a post-rational position is the surrendering to difference at a subjective and dialogical level. This means that to demand peace would necessarily involve demanding 'a new mode of thinking, a new mode of becoming' (Cubitt 2002:12). Becoming, or that which not-yetis, stands central to Cubitt's argument as it allows peace to be understood as transitory, originating in dialogue and characterised by change. Dietrich et al. (2011) similarly problematises peace as a normative and universal concept by arguing that any conception thereof should be guided by transrationality. For these authors, this entails considering peace, and the historical and contemporary practices thereof, from within different cultural frameworks. This they argue will enable one to avoid the Eurocentric foundations prevalent in much of the peace studies field. Grounding any understanding of peace within transrationality also allows for it to be understood as 'a dynamic, relational network of interaction and communication' (Dietrich 2011:13), thus rendering any normative and universalised notion of peace as relative. The consequence of this is that the concept of peace is dissolved into a plurality of peaces.

The difficulty of defining peace as it finds expression within peace education and the practice thereof have led scholars such as Ben-Porath (2003:525) to argue that the field 'is in fact so broad that authors disagree on the description of the problem they wish to address and correspondingly on the proper solution, as well as on the site in which peace education is taking place'. For others such as Harris (2004:8), the nebulous nature of peace education is not problematic because "[e]ach branch of this peace education family has different theoretical assumptions about the problems of violence it addresses, different peace strategies it recommends and different goals it hopes to achieve'. As such, various approaches ranging from human rights education, education for gender equality, environmental education, and education for reduction of violence in schools, to international and development education and conflict resolution are understood as a form of peace education (see, e.g. BenPorath 2003; Harris 2004; Zembylas \& Bekerman 2013). Danesh (2005) has attempted to argue for a unified theory of peace education that encompasses all these various fields within his theory of integrative peace education but this position has come under direct and indirect critique by scholars such as Bajaj (2008), Gur-Ze'ev (2001, 2010) and Zembylas and Berkerman (2013) ${ }^{2}$ who have all pointed out that such a position fails to question the fundamental philosophical and theoretical assumptions of the field that normalise particular ways of understanding and pedagogical practices. In this regard, Bajaj (2008) argues that research should aim at gaining a better understanding of local knowledge, meanings and experiences of peace education. This call is echoed by Dietrich et al. (2011) who argue that

2.1t has to be made clear that these are not the only schola.......................... integrative approach of peace education or an understanding of peace education integrative approach of peace education or an understanding of peace education that develops from a normative or universalised understanding of peace and violence. For the purposes of this article, we, however, only focus on how these scholars understand peace education. 
researchers and practitioners should avoid constructing metanarratives regarding the nature of peace and violence while remaining ignorant of local concepts and histories thereof and struggles towards this end. Waterhouse (2011:90) refers to approaches that remain ignorant of local concepts and histories as 'violence against diverse ways of knowing', while Zembylas and Bekerman (2013:199) point out that such a position 'undermines local understandings of how participants can cultivate a sense of transformative agency on the basis of contextual values and truth claims'.

Gur-Ze'ev (2001:315) argues that the thin philosophical and theoretical foundations on which peace education rests, and from which universal conceptualisation of peace arise, emerge from a position that posits 'philosophical work ... as unnecessary, artificial, or even dangerous for this educational cause'. This in turn allows for an 'ahistorical or homogenized [sic] perspective, as if there was one universal theory that could encompass everything' (Zembylas \& Bekerman 2013:199). In contrast to this, Zembylas and Bekerman propose an understanding of peace education that acknowledges multiplicity, contingency and complexity because any essentialist, normalised and universalised understanding thereof fails to recognise the multiple representations of truth and understandings of justice that emerge from within differing temporal and spatial contexts. To support this proposition, Zembylas and Bekerman aver that nouns such as conflict and peace, and adjectives such as peaceful and violent, are not true representations of the world because they do not possess predetermined forms. Instead of considering words 'as prepacked discrete units readily available for implementation in social life' (Zembylas \& Bekerman 2013:204), they should rather be understood as 'reflective accomplishments'. Such an understanding allows for words to be posited as 'tricky constructs whose meaning is negotiated by active participants and put to work in complex social relations' (Zembylas \& Bekerman 2013:204). Such meaning is furthermore also 'bounded in the materiality of "things" and the practices within which concepts are performed, contextually and historically' (Zembylas \& Bekerman 2013:205). Zembylas and Bekerman's proposition that concepts such as peace and violence have no fixed meaning in and of themselves but have to be performed, offer a welcome refrain on Deleuze's (1995) and Deleuze and Guattari's (1987) assertion that it is not what a word signifies that is important, but rather what it does and how it functions; in other words, its potential to enable transformation. We lastly consider Gur-Ze'ev's (2010) suggestion that peace education should be founded on copoiesis $^{3}$ and improvisation.

In contrast to most conventional approaches to peace education that hold a utopian vision of a future world comprised of a redeemed humanity, Gur-Ze'ev $(2010,2011)$ calls for counter-education premised on an understanding of peace as responsible improvisation and co-poiesis. Such an

3.Gur-Ze'ev (2011:113) understands co-poiesis to be 'a new kind of togetherness and new realizations of responsibility in the face of the apparent deconstruction of the humanist ethics and its universal value and truth claims'. education, he argues, is made possible through foregrounding the importance of the ethical ' $\mathrm{I}$ ' as it finds expression within the immediacy of an event. This Gur-Ze'ev avers makes 'possible becoming-toward-the-world' through 'creativity that gives birth to alternative togetherness, to openness and responsible improvisation' (Gur-Ze'ev 2011:111). It is through the practice of responsible improvisation and copoiesis that we create the conditions in which peace can be edified anew in every moment. Given this, an argument can be made that we should not only seek to determine what concepts (such as peace and violence) mean through our research and teaching and learning practices. Rather, we should create explorative opportunities to experiment with what such concepts can do and the possibilities for transformation they make possible and the forms such transformations may take. If one takes up Gur-Ze'ev's position, it would mean that peace education should enable the practice of an ethics of immanence that seeks to maximise one's 'affective power (puissance), extending connections, and forming life-affirming assemblages' (Waterhouse 2011:147). In other words, an approach that emphasises that it is through our responsible improvisation towards-thebecoming-world that we create openings for performing 'possibilities of worlds we haven't yet thought' (St Pierre 2013:226).

The arguments of Cubitt (2002), Dietrich et al. (2011), and to a certain extent, Webel (2007) are important for rethinking the concept of peace and how it finds expression within peace education. This is evident if one considers Bajaj's (2008) assertion that any understanding and practice of peace emerges from a particular socio-political context. Zembylas and Bekerman $(2013: 199$, 205) similarly argue that it is through negotiated performances within 'complex social relations ... bounded in the materiality of "things"' that any understanding of peace emerges. The performative aspect is also foregrounded by Gur-Ze'ev $(2010,2011)$ through his call for responsible improvisation and co-poiesis. The notion of peace as change, as transitory, as dialectical and peace education as a contextually determined practice founded on an ethics of immanence potentially opens up new possibilities for mapping the connections between peace education and TESOL. To explore this, we read the connections between peace education and TESOL through an MLT lens to consider the transdisciplinary possibilities that doing so facilitates.

\section{Reading the connections between peace education and teaching English to speakers of other language through multiple literacies theory}

Given the nebulous nature of peace education, the manner in which it has been taken up in TESOL has spawned an array of subfields. These include approaches such as international or global education (Jacobs 1990; Yoshimura 1993), intercultural communication (Bruneau 2000) and caring communication (McInnis 1998). More recently, peace 
linguistics (Crystal 2003), peace sociolinguistics (Friedrich 2007) and content-based language instruction that incorporate peace-related content (Allan 2011; Kubota 2016) have come to the fore. Given the current prominence of humanistic and communicative approaches within the field of TESOL, a focus on incorporating aspects of peace education that promote communicative peace, peace building and peace maintaining practices through language is understandable (see, e.g. Friedrich 2007; Kruger 2012; McInnis 1998; Morgan \& Vandrick 2009). For as Gomes de Matos (n.d.:2) states: 'as language users/learners we have both the right and the responsibility of communicating well (appropriately, accurately, meaningfully) and of communicating for the good of humankind'. The manner in which aspects of peace education are incorporated in TESOL thus focuses not only on making 'peace with language' but also on making 'peace through language' (Friedrich 2007:73).

In working from an MLT perspective, Waterhouse (2011:81) argues that a 'litany of peace literacies' is produced given the manner in which peace education informs TESOL. Within all of these literacies, the notion of literacy becomes effectively reduced 'to a set of skills and knowledge, to an outcome and product' (Waterhouse 2011:81). Such an understanding is premised on the assumption that learning unfolds linearly and programmatically. As has been argued earlier, understanding literacy development in a linear fashion does not take into consideration the dynamic processes that produce unforeseen transformations through investment in becoming-literate. Similarly, from an MLT perspective, the manner in which peace education informs TESOL should not reduce gaining communicative peace to a predetermined set of linguistic and communicative skills whose development trace a programmatic trajectory. Employing MLT, we argue, potentially allows one to take different aspects of becoming-literate into consideration when exploring the transdisciplinary connections between peace education and TESOL. This could be achieved by paying attention to the dynamic affective, discursive and material processes that are involved in and inform gaining communicative peace. In this manner, gaining communicative peace can be understood as a reflective accomplishment which responds to the argument presented by Zembylas and Bekerman (2013:205) that concepts such as peace are 'bounded by the materiality of "things" and the practices within which concepts are performed, contextually and historically'. Deleuze and Guattari (1987) assert that language is not only a discursive but also a material practice that works on the world through speech and through transforming bodies. This understanding of language is also proposed by Lecercle and Riley (2004:69) who points out that although language may not physically change the body, 'it leaves traces, or inscriptions' on the body. As performative, language is thus not descriptive of the world but inhibits the world. As MLT enables one to consider 'how thought [and action] might arise in education and through educational contexts' (Cole 2012b:5), it will arguably provide an opening to explore how the 'language of peace' and the experiences thereof in the TESOL context give rise to the thought about and action towards peace.
We furthermore argue that MLT enables one to address a second concern raised, namely that the normative and universal definitions proposed for the key concepts on which peace education rests are uncritically incorporated into TESOL. This critique includes an understanding that not taking a critical stance towards the fundamental premises that inform peace education has as consequence that peace (and by implication peace education) is treated as a deontological 'thing' (Page 2008; Zembylas \& Bekerman 2013). As a concept that is deontologised and universalised, it can be argued to perpetuate Eurocentric value and knowledge positions at the expense of 'cultivating a sense of transformatory agency on the basis of contextual values and truth claims' (Zembylas \& Bekerman 2013:199). Deleuze and Guattari (1994:83) similarly critique concepts representing a universal 'truth' because such concepts are 'too regular, petrified, and reduced to a framework ... the most universal concepts, those presented as eternal forms or values are the most skeletal and least interesting'. From an MLT perspective, a concept such as peace is not understood as meaningful in and of itself. Rather in following Colebrook (2010:1), a concept, such as peace, is intensive in that it 'does not gather together an already existing set of things' but rather 'allow[s] for movement and connection'. If one works from the premise that any understanding of peace is always emergent, developing from 'a dynamic, relational network of interaction and communication' (Dietrich 2011:13), it implies that peace is invented through performance (Waterhouse 2011; Zembylas \& Bekerman 2013). As such, TESOL educators cannot provide learners with promises of 'meaning, truth, consensus, justice and peace' (Gur-Ze'ev 2001:336) but should rather respond 'to these difficult ambivalent spaces of unknowability' (Waterhouse 2011:95) with responsible improvisation (GurZe'ev 2011). Taking an MLT stance arguably allows for interrogating the manner in which peace is invented and performed within the TESOL context and the transformations that this produces because MLT foregrounds the flows of life experiences and events through which individuals becomingliterate.

Lastly, we consider the importance of context. Literacies become actualised within specific contexts, being 'tied up with relations of power across various dimensions of difference (gender, race, class, religion, etc.)' (Waterhouse 2011:82). From an MLT perspective, mapping when and how peace is performed should reflect sensitivity to the spatial and temporal context such performances occur in and the power relations that permeate these contexts. Assuming similarities across different contexts, as is done in most conventional approaches to incorporating peace education in TESOL, is thus highly problematic. Gale (2010:304) argues that the 'territories of teaching and learning are not fixed, stable, and unchanging but that they are spaces of flux, viral contagion, and transmutation'. Given this, what is of interest for researchers working from an MLT perspective is how various aspects of peace education find expression and become valued and are practised in different language learning contexts and between different groups of people. In this regard, the transdisciplinary connections between peace 
education and TESOL could be made sense of in terms of constituting an assemblage. According to Masny (2016:668), assemblages consist of content, the relationship between human, animal, vegetal, and social bodies, 'the social nature of language and the discourse that emerges from the assemblage and the discourse that produces the assemblage'. Examining the peace education and TESOL assemblage would thus entail not so much seeking to discover what it means or represents but how it functions and what it produces; how various bodies come together, collide and transform within specific contexts and the material and discursive practices these produce.

\section{Conclusion}

The descriptions provided about the manner in which MLT can inform how we make sense of the connections between peace education and TESOL are not exhaustive but rather serve as an introduction to the potential that such an approach may hold. Furthermore, by critiquing the conventional ways in which peace education inform TESOL, we do not wish to discredit the important work being carried out in this regard and the contribution that TESOL educators make in peace building and peace maintaining projects. Rather, through our employment of MLT, we aim to create opportunities for the generation of different knowledge that explore the affective, material and discursive connections these fields may produce and the unforeseen transformations made possible. In working from a position of difference (Deleuze 1994), what such transformations may entail and to which ends they occur cannot be known in advance. What an MLT approach offers rather is a means to explore the affective, material and discursive connections between peace education and TESOL, and to become aware of transformations that these connections make possible and produce. Multiple literacies theory furthermore offers a way to map these possibilities and that which is produced through such connections. This mapping occurs in the border region between the present and the future, or that which Foucault (1972:130) refers to as the 'border of time that surrounds our present, which overhangs it, and which indicates its otherness ...' . It is by working at the borders - the transdisciplinary connections between peace education and TESOL - that enables one to explore that which is in the process of coming about ... [that] what we are in the process of becoming ... our becoming-other' (Deleuze \& Guattari 1994:111, 112, our emphasis).

Multiple literacies theory furthermore allows one to explore 'the multiplicities of literacies' (Masny \& Cole 2009:10) present in language learning contexts. We argue that in considering how peace education informs TESOL, MLT allows one to investigate and comment on the multiplicities of literacies on peace and violence and the transformations that are brought about as one invests in reading, reading the self and reading the world (see, e.g. Waterhouse 2011). It is through mapping such transformations that opportunities are created to explore and experiment with how peace and violence become conceptualised, valued and practised by language learners in particular contexts. In this regard, we are reluctant to be prescriptive because, as we argued earlier, teaching and learning unfold differently across different contexts. What MLT does offer, however, is to serve as a means for both researchers and TESOL and peace education teachers to become sensitive to and interested in investigating the effect of affect on teaching and learning, as well as the untimely becomings that educational encounters produce. Multiple literacies theory thus offers a means by which 'new [and different] possibilities in education can be seen which take away the normative blueprints for development that currently exists' (Cole 2013b:64). By doing this, MLT, and for our argument specifically how it relates to the transdisciplinary connections between peace education and TESOL, creates the possibilities to make evident the 'multiple and minor literacies' (Cole 2013a:64) through which the concepts of peace and violence are negotiated and becomes actualised as teachers and students read the word, the world and the self.

\section{Acknowledgements Competing interests}

The authors declare that they have no financial or personal relationships which may have inappropriately influenced them in writing this article.

\section{Authors' contributions}

F.K. as a PhD student (contributed 75\%) and R.E. as a supervisor (contributed 25\%) contributed to the conceptualisation, drafting and editing of the final manuscript.

\section{References}

Allan, T., 2011, 'Pedagogies of peace education as a content-based subject among second language learners in Nagasaki, Japan', Unpublished doctoral thesis, Macquire University, Sydney.

Bajaj, M., 2008, 'Critical peace education', in M. Bajaj (ed.), Encyclopaedia of peace education, pp. 135-146, Information Age Publishing, Charlotte, NC.

Ben-Porath, S., 2003, 'War and peace education', Journal of Philosophy of Education 37(3), 525-533. https://doi.org/10.1111/1467-9752.00342

Bernstein, J.H., 2015, 'Transdisciplinarity: A review of its origins, development, and current issues', Journal of Research Practice 11(1), Article R1, viewed 02 November 2017, from http://jrp.icaap.org/index.php/jrp/article/view/510/412

Bruneau, T., 2000, 'Peace communication: The ethics of caring across cultures', in L.A. Samovar \& R.E. Porter (eds.), Intercultural communication: A reader, 9th edn., pp. 455-462, Wadsworth Publishing Company, Belmont, CA.

Cole, D.R., 2012a, 'Latino families becoming-literate in Australia: Deleuze, literacy and the politics of immigration', Discourse: Studies in the Cultural Politics of Education 33(1), 33-46. https://doi.org/10.1080/01596306.2012.632160

Cole, D.R., 2012b, 'Matter in motion: The educational materialism of Gilles Deleuze', Educational Philosophy and Theory 44, 3-17. https://doi.org/10.1111/j.14695812.2010.00745.x

Cole, D.R., 2013a, 'Deleuze and narrative investigation: The multiple literacies of Sudanese families in Australia', Literacy 47(1), 35-41. https://doi.org/10.1111/ lit.12000

Cole, D.R., 2013b, 'Deleuze and the subversion(s) of "The Real": Pragmatics in education', in D. Masny (ed.), Cartographies of becoming in education: A Deleuze Guattari perspective, pp. 53-69, Sense Publishers, Rotterdam.

Colebrook, C., 2002, Gilles Deleuze, Routledge, New York.

Colebrook, C., 2010, 'Introduction', in A. Parr (ed.), The Deleuze Dictionary revised edition, 2nd edn., pp. 1-6, Edinburgh University Press, Edinburgh.

Colman, F.C., 2010, 'Rhizome', in A. Parr (ed.), The Deleuze Dictionary revised edition, 2nd edn., pp. 232-235, Edinburgh University Press, Edinburgh.

Crystal, D., 2003, Dictionary of linguistics and phonetics, Blackwell, Oxford. 
Cubitt, S., 2002, 'To transitory peace', International Journal of Cultural Studies 5(1), 11-19. https://doi.org/10.1177/13678779020050010201

Cummins, J., 2008, 'BICS and CALP: Empirical and theoretical status of the distinction', in B. Street \& N.H. Hornberger (eds.), Encyclopedia of language and education: Literacy, pp. 71-83, Springer Science, New York.

Danesh, H.B., 2005, 'Towards an integrative theory of peace education', Journal of Peace Education 3(1), 55-78. https://doi.org/10.1080/17400200500532151

Deleuze, G., 1994, Difference and repetition, transl. P. Patton, Continuum, New York.

Deleuze, G., 1995, Negotiations: 1972-1990, transl. M. Joughin, Columbia University Press, New York.

Deleuze, G. \& Guattari, F., 1987, A thousand plateaus: Capitalism and schizophrenia, transl. B. Massumi, University of Minnesota Press, Minneapolis, MN.

Deleuze, G. \& Guattari, F., 1994, What is philosophy? transl. H. Tomlinson \& G. Burchell, Columbia University Press, New York.

Dietrich, W., 2011, 'Beyond the gates of Eden: Trans-rational peaces', in W. Dietrich, J.E. Alvarez, G. Esteva, D. Ingruber \& N. Koppensteiner (eds.), The Palgrave International handbook of peace studies: A cultural perspective, pp. 3-23, Palgrave Macmillan, New York.

Dietrich, W., Alvarez, J.E., Esteva, G., Ingruber, D. \& Koppensteiner, N. (eds.), 2011, The Palgrave International handbook of peace studies: A cultural perspective, Palgrave Macmillan, New York.

Foucault, M., 1972, The archaeology of knowledge and discourse on language Pantheon Books, New York.

Friedrich, P., 2007, 'English for peace: Toward a framework of peace sociolinguistics', World Englishes 26(1), 72-87. https://doi.org/10.1111/j.1467-971X.2007.00489.x

Gale, K., 2010, 'An inquiry in to the ethical nature of a Deleuzian creative educational practice, Qualitative Inquiry 16(5), 303-309. https://doi.org/10.1177/1077800 409358869

Gomes de Matos, F., n.d., Toward a pedagogy of peaceful communication, viewed from www.atriumlinguarum.org/contenido/Peace.pdf

Gur-Ze'ev, I., 2001, 'Philosophy of peace education in a postmodern era', Educational Theory 51(3), 315-336. https://doi.org/10.1111/j.1741-5446.2001.00315.x

Gur-Ze'ev, I., 2010, 'Beyond peace education: Toward co-poiesis and enduring improvisation', Policy Futures in Education 8(3 \& 4), 315-339. https://doi.org/ 10.2304/pfie.2010.8.3.315

Gur-Ze'ev, I., 2011, Diasporic philosophy and counter-education, Sense Publishers, Rotterdam.

Harris, I.M., 2004, 'Peace education theory', Journal of Peace Education 1(1), 5-20. https://doi.org/10.1080/1740020032000178276

Jacobs, G., 1990, 'ESOL and international education', TESOL Newsletter 24(1), 27.

Jordaan, H., 2011, 'Language teaching is no panacea: A theoretical perspective and critical evaluation of language in education within the South African context', South African Journal of Communication Disorders 58(2), 59-71. https://doi. org/10.4102/sajcd.v58i2.29

Kruger, F., 2012, 'The role of TESOL in educating for peace', Journal of Peace Education 9(1), 17-30. https://doi.org/10.1080/17400201.2011.623769
Kubota, R., 2016, 'Critical content-based instruction in the foreign language classroom: Critical issues for implementation', in L. Cammarata (ed.), Content-based foreign language teaching: Curriculum and pedagogy for developing advanced thinking language teaching: Curriculum and pedagogy for devel
and literacy skills, pp. 192-212, Routledge, New York.

Lecercle, J.-J. \& Riley, D., 2004, The force of language, Palgrave MacMillan, New York.

Masny, D., 2009, 'Literacies as becoming: A child's conceptualizations of writing systems', in D. Masny \& D.R. Cole (eds.), Multiple literacies theory: A Deleuzian perspective, pp. 13-30, Sense Publishers, Rotterdam.

Masny, D., 2010, 'Multiple literacies theory: How it functions, what it produces', Perspectiva 28(2), 337-352.

Masny, D., 2016, 'Problematizing qualitative research: Reading a data assemblage with Rhizoanalysis', Qualitative Inquiry 22(8), 666-675. https://doi.org/10.1177/ 1532708616636744

Masny, D. \& Cole, D.R., 2009, 'Introduction to multiple literacies theory: A Deleuzian perspective', in D. Masny \& D. R. Cole (eds.), Multiple literacies theory: A Deleuzian perspective, pp. 1-11, Sense Publishers, Rotterdam.

Masny, D. \& Waterhouse, M., 2011, 'Mapping territories and creating nomadic pathways with multiple literacies theory', Journal of Curriculum Theorizing 27(3), 287-307.

Masny, D. \& Waterhouse, M., 2016, 'Capitalism, immigration, language and literacy: Mapping a politicized reading of a policy assemblage', Policy Futures in Education 14(7), 1005-1019. https://doi.org/10.1177/1478210316663393

McInnis, D.J., 1998, 'Caring communication in the language classroom', Peace Review 10(4), 539-543. https://doi.org/10.1080/10402659808426200

Morgan, B. \& Vandrick, S., 2009, 'Imagining a peace curriculum: What second language education brings to the table', Peace and Change 34(4), 510-532. https://doi.org/10.1111/j.1468-0130.2009.00598.x

Page, J.S., 2008, Peace education: Exploring ethical and philosophical foundations, Information Age Publishing, Charlotte, NC.

Pennycook, A., 2006, 'The myth of English as an international language', in S.B. Makon \& A. Pennycook (eds.), Disinventing and reconstituting language, pp. 90-115, Multilingual Matters, Clevedon.

Phillipson, R., 2009, Linguistic imperialism continued, Routledge, London.

St Pierre, E.A., 2013, 'The appearance of data', Cultural Studies $\leftrightarrow$ Critical Methodologies 13(4), 223-227. https://doi.org/10.1177/1532708613487862

Waterhouse, M., 2011, 'Experiences of multiple literacies and peace: A Rhizoanalysis of becoming in immigrant language classrooms', Unpublished doctoral thesis, University of Ottawa, Ontario, viewed 02 October 2012, from www.ruor.uottawa. ca/en/handle/10393/19942

Webel, C., 2007, 'Toward a philosophy and metapsychology of peace', in C. Webel \& J. Galtung (eds.), Handbook of peace and conflict studies, pp. 3-13, Routledge, Oxon.

Yoshimura, M., 1993, 'Teaching global issues to children', The Language Teacher 17(5), $11-15$.

Zembylas, M. \& Bekerman, Z., 2013, 'Peace education in the present: Dismantling and reconstructing fundamental theoretical premises', Journal of Peace Education 10(2), 197-214. https://doi.org/10.1080/17400201.2013.790253 